\title{
Ewa Paczkowska
}

\section{Magia, czarownice, prześladowania - prawda czy średniowieczny mit?}

W XXI w., w świecie racjonalizmu, potęgi rozumu i rozwoju techniki, słowo „Czarownica” jest utożsamiane przede wszystkim z baśniami, a także postacią kobiety „posługującej się czarami” - najczęściej kojarzonej negatywnie. Taki wizerunek kobiety sięga do realiów XVI w., w którym wzrosła liczba spraw sądowych, toczonych głównie przeciw kobietom, posądzanych m.in. o paranie się magią ${ }^{1}$. Nasuwa się pytanie, czym było zjawisko, określane mianem „magii” oraz w jakiej było relacji do religii i nauki?

\section{Magia a religia i nauka}

Opierając się na hasłach słownikowych, można zdefiniować magię jako „ogół wierzeń i praktyk opartych na przekonaniu o istnieniu mocy nadprzyrodzonych, które można opanować i wywoływać za pomocą zaklęć, obrzędów i czarów; niezwykła siła oddziaływania2 oraz zniewalający urok

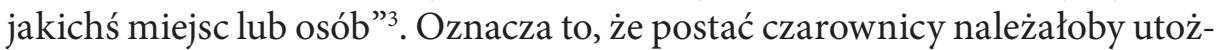
samiać z osobą posiadającą moce nadprzyrodzone, która za pomocą odpowiednich zaklęć osiągała wyznaczony cel. Między XIV a XVIII w. siły te kojarzono z Szatanem, pod wpływem którego znajdowała się taka kobieta. Dlatego czarownica może oznaczać „według dawnych wierzeń ludowych: kobietę podlegającą wpływom diabła, mającą moc rzucania uroków”" Ponieważ postać diabła była i jest nieodłączną częścią wierzeń oraz religii, dla szerszego spektrum należy ustalić, jak zdefiniowana jest sama religia. Jest ona określana jako „zespół wierzeń dotyczących istnienia Boga lub bogów, pochodzenia i celu życia człowieka, powstania świata oraz związane z nimi

1 B. P. Levack, Polowanie na czarownice w Europie wczesnonowożytnej, Wrocław 2009, s. 262-263.

2 Słownik PWN, http://sjp.pwn.pl/sjp/magia;2480459 [dostęp: 26.01.2015].

Ibidem.

4 Słownik PWN, http://sjp.pwn.pl/szukaj/czarownica.html [dostęp: 26.01.2015]. 
obrzędy, zasady moralne i formy organizacyjne" ${ }^{\text {. Na }}$ podstawie przedstawionych definicji, dotyczących magii, postaci czarownicy oraz religii, można zauważyć tendencję do pojawiania się w nich słowa „wierzenie”. Powstaje zatem kwestia, czy to, w co wierzymy, jest równoznaczne z prawdą, czy też jest to jedynie nasz subiektywny pogląd. W celu ukazania relacji zachodzącej pomiędzy magią a religią można przywołać przykład biblijnej Księgi Powtórzonego Prawa, gdzie czytamy:

Niech się u ciebie nie znajdzie nikt, kto by przeprowadzał przez ogień swego syna albo córkę, [kto] uprawiałby wróżbiarstwo, zamawianie, zaklinanie czy też magię lub kto odwoływałby się do czarów, kto zwracałby się z pytaniem do duchów, do jasnowidzów, ani też kto poszukiwałby rady u umarłych. Każdy kto tak bowiem postępuje, budzi wstręt u Jahwe [...]. (Pwt. 18, 10-12)6.

Biblia odróżnia cuda, które są dziełem Boga, od magii, będącej działaniem demona. Jednak po raz kolejny pojawia się pytanie, co powinno być uznawane za cud, a co za działanie sił nieczystych. Interpretowanie przed Mojżeszem procesu rozstąpienia się Morza Czerwonego jako działania magicznego, a tym samym nazywanie Boga magiem, zostanie uznane za herezję przez ludzi, dla których ten czyn jest cudem i dowodem wielkości oraz nieograniczonej mocy Boga - wyzwoliciela narodu żydowskiego.

Również nauka nie była wolna od powiązań z magią. Starożytny Egipt uważano w III w. n.e. za ojczyznę czarowników7. W Mezopotamii, krainie, w której miały miejsce wielkie osiągnięcia w dziedzinach astronomii i matematyki, wiedzę o planetach wykorzystywano do przepowiadania przyszłości. Babilończycy utożsamiali planety z różnymi bogami ${ }^{8}$. Wraz z rozwojem nauki magia zaczęła tracić swoje znaczenie, co doprowadziło do jej ograniczenia i pojawiania się pod postacią wątków magicznych w legendach różnych krajów. Jednym z przykładów jest mitologia starożytnej Grecji, występująca tam postać Odyseusza i jego powrót z wojny trojańskiej oraz Kirke

5 Słownik PWN, http://sjp.pwn.pl/szukaj/religia.html [dostęp: 26.01.2015].

6 Pismo Święte. Stary i Nowy Testament, red. ks. M. Peter, ks. M. Wolniewicz, Poznań 2003, s. 225.

7 Miano to nadał Egiptowi Klemens Aleksandryjski, który magię i ezoterykę wiązał z najstarszą i najbardziej podziwianą kulturą; D. Alexander, Spellbound. From Ancient Gods to Modern Merlins. A Time Tour of Myth and Magic, London 2002 (polskie wydanie: Czarownice, wróżbici, szamani. Podróż przezświat mitów i magii, tłum. J. Korpanty, Warszawa 2008, s. 18-19).

8 Przepowiadanie przyszłych zdarzeń odbywało się poprzez obserwację planet, które były kojarzone z poszczególnymi bogami; ibidem, s. 15-16. 
używająca magicznych mikstur9. W mitologii celtyckiej można spotkać postaci Tristana i Izoldy Jasnowłosej ${ }^{10}$, czarodzieja Merlina oraz króla Artura i jego Rycerzy Okrągłego Stołu ${ }^{11}$.

\section{„Magiczne” zaklęcia i rytuały}

Ze względu na liczne epidemie oraz powszechnie panujący głód stosowanie zaklęć było w średniowieczu bardzo rozpowszechnione. „Magiczne formuły" miały za zadanie chronić ludzi przed śmiercią, chorobami u zwierząt czy też spowodowaniem szkód w gospodarstwie. Zaklęć używano także w celu polepszenia swojego bytu, a przede wszystkim - jako ochrony przed zarazami, które w średniowiecznej Europie rozprzestrzeniały się niezwykle szybko. W wielu krajach stosowano różnego rodzaju rytuały. Począwszy od mało inwazyjnych, jak błogosławienie nowo wybudowanego domu (średniowieczna Rumunia), poprzez liczne audiencje odbywające się na dworze króla, podczas których jego dotyk przy jednoczesnym czytaniu Biblii przez kapłana miał leczyć z wrzodów czy guzów ${ }^{12}$ (dwunastowieczna Anglia i Francja), a kończąc na rytuałach bardziej drastycznych, jak upuszczanie krwi choremu w celu osiągnięcia równowagi humorów ${ }^{13}$ (co jeszcze bardziej pogarszało

9 Kirke pojawia się w mitologii jako córka Słońca, czarodziejka, która za pomocą magicznych ziół nakarmiła, a następnie przemieniła towarzyszy Odyseusza w świnie. Mimo że legenda może być uważana w dzisiejszym świecie za mit, w okresie polowań na czarownice posądzonym o czary przypisywano wykorzystywanie ziół; J. Parandowski, Mitologia. Wierzenia i podania Greków i Rzymian, Londyn 1992, s. 257.

10 Mit o Tristanie i Izoldzie oraz napoju, który połączył ich uczuciem, miał tak znaczący wpływ na kulturę współczesną, że można odnaleźć przepis na przyrządzenie magicznej mikstury wraz z kolejnymi etapami przygotowania; B. Bioque, Wstęp do magii, tłum. E. Morycińska-Dzius, Warszawa 2014, s. 150.

11 Chociaż istnienie historycznej postaci króla Artura jest podawane w wątpliwość, to jednak zarówno on, jak i jego rycerze byli uważani przez ludność średniowieczną za bohaterów godnych naśladowania; Mitologie Świata. Celtowie, red. J. Kałużna-Ross, Warszawa 2007, s. 105-115.

12 Duchowni nie traktowali owych zabiegów jako przejawu magii, a jedynie uważali za znak błogosławieństwa króla, którego działania mogły, ale nie musiały, być dostrzeżone przez Boga, co w konsekwencji oznaczało, że chory mógł pozostać nadal chory, mimo kolejnych modlitw. Dla prostego ludu natomiast, stosowane zabiegi były czysto magiczne, a króla uważano za posiadającego błogosławieństwo Boskie; D. Alexander, Spellbound. From Ancient Gods..., s. 109-110.

13 Już w starożytności uważano, że ciałem rządzą cztery „humory”: wilgoć, zimno, suchość i gorąco. Kiedy równowaga między nimi została zachwiana, występowała 
jego stan zdrowia) czy wiara, iż stosunek z dziewicą uleczy z syfilisu żołnierzy amerykańskich podczas pierwszej wojny światowej ${ }^{14}$. W czasie odprawiania rytuałów bardzo powszechnym zjawiskiem było wykorzystywanie roślin czy zwierząt jako leku. Kształt, kolor czy właściwości roślin kojarzono ze schorzeniami występującymi u pacjenta. Osobie chorej na żółtaczkę podawano rośliny w kolorze żółtym. Sałata, wilgotna i zimna, miała za zadanie koić podrażnioną skórę. Mandragory, korzenia przypominającego kształtem człowieka, używano jako środek znieczulający. Także zwierzęta miały posiadać właściwości lecznicze ${ }^{15}$.

\section{Ramy czasowe polowań na czarownice}

W przeciwieństwie do popularnego wierzenia, polowanie na czarownice nie miało swojego apogeum w średniowieczu, a we wczesnych czasach nowożytnych. Chociaż pierwsze doniesienia o sprawach sądowych pojawiają się z początkiem XIV w., były to głównie sprawy o maleficium, wiążące się z czynieniem zła lub szkodzeniem wrogom politycznym. Z czasem do maleficium zostały włączone sprawy dotyczące oskarżeń o satanizm. W pierwszym okresie polowań (pomiędzy rokiem 1420 a 1520) pojawiły się traktaty mówiące o czarostwie. Dzieła Johannesa Niedera Formicarius, Heinricha Kramera Malleus Maleficarum bądź też Urlicha Molitora De Lamiis et Phitonicis Mulieribus przyczyniły się do wszczęcia kolejnych rozpraw przeciwko posądzonym o czary ${ }^{16}$. Początek XVI w. był czasem wyciszenia tych procesów, co miało związek z rozwojem humanizmu, wraz z którym zmieniło się podejście człowieka do otaczającego go świata. Także reformacja odwróciła uwagę ludzi od problemu czarownic i skierowała ją w stronę nowo powstałego problemu, jakim był rozłam Kościoła. Dopiero w drugiej połowie XVI oraz na początku XVII w. można mówić o regularnych i masowych polowaniach

choroba. Upuszczanie krwi miało przyczynić się do ponownego przywrócenia równowagi „humorów”, co w konsekwencji zbijało gorączkę oraz poprawiało stan fizyczny pacjenta. Metoda upuszczania krwi była stosowana do XIX w.; ibidem, s. 124-125.

\section{ści} ści kogut jest lekarstwem na suchoty. Często dochodziło do niedorzecznych, z perspektywy XXI w., rytuałów (np. mieszanie miodu z ekskrementami kozła w celu uleczenia raka piersi). Ponadto wierzono, że zwiększone cierpienie zwierząt przyczyni się do lepszego oddziałania na ludzi; ibidem, s. 126-137.

16 Wspomniane traktaty mówiły o czarownicach, wróżkach i postępowaniach satanistycznych; ibidem, s. 262-263. 
na czarownice. Głównej przyczyny można doszukiwać się w ponownej intensyfikacji publikacji rozprawiających o czarownicach, które dzięki wynalazkowi druku stały się o wiele bardziej dostępne dla szerszego kręgu ludności. Duże znaczenie $\mathrm{w}$ walce $\mathrm{z}$ praktykami magicznymi miało podejście do kwestii prowadzenia postępowań sądowych oraz sposób zbierania dowodów przeciwko oskarżonym. W zależności od kraju stosowano, bądź też zakazywano stosowania tortur podczas przesłuchań. W Anglii, do uznania winnym nie było wymagane przyznanie się do czarostwa. W zamian mogły temu służyć inne dowody świadczące o winie oskarżonego. W konsekwencji nie istniały ograniczenia dotyczące ilości oskarżonych i skazanych za praktykowanie magii. Z kolei w Szkocji stosowano niekiedy okrutne tortury, podczas których ofiary podawały ciąg nazwisk osób rzekomo będących czarownicami ${ }^{17}$. W Polsce, przyznanie się do winy było niezbędne, a mogło ono nastąpić dobrowolnie lub poprzez wykorzystanie tortur ${ }^{18}$. Dopiero w drugiej połowie XVII w. można mówić o końcowym etapie polowań na czarownice - wówczas państwa zaczęły wydawać ograniczające tę działalność dekrety. Do końca XVIII w. zaprzestano przeprowadzania masowych procesów o czary. W zależności od kraju, daty zakończenia polowań na czarownice różnią się między sobą ${ }^{19}$.

\section{Kogo posądzano o czary?}

Według średniowiecznej opinii, magiczne predyspozycje mogły posiadać osoby trudniące się zawodem kowala, uzdrowiciela, opiekunki do dzieci bądź też akuszerki. Nawiązując do tych ostatnich, było to związane z koniecznością stosowania niekonwencjonalnych metod leczenia. Akuszerki były w szczególności narażone na posądzenie o czary ze względu na

17 W Szkocji intensyfikację polowań na czarownice można zauważyć za czasów panowania Jakuba VI. W swoim dziele Demology, wydanym w 1597 r., mówi on o Szatanie, chcącym zapanować nad światem. Za tak liczne występowanie czarownic obwinia katolików, którzy są przeciwni wierze protestanckiej. Jakub VI niekiedy sam przesłuchiwał oskarżonych o czary oraz brał udział w torturach tak bolesnych, że przesłuchiwany przyznawał się do wszystkich zarzucanych mu czynów; K. Baschwitz, Czarownice. Dzieje procesów o czary, tłum. T. Zabłudowski, Warszawa 1999, s. 153-162.

18 B. Baranowski, Procesy czarownic w Polsce w XVII i XVIII w., Łódź 1952, s. 97-110.

19 Ostatnią egzekucją czarownic przeprowadzoną w Europie była ta z 1782 r. w Szwajcarii. Egzekucja, która odbyła się w Polsce w 1793 r., była najprawdopodobniej bezprawna; B. P. Levack, Polowanie na czarownice..., s. 266-270. 
wykonywanie profesji obcej mężczyznom, a zatem budzącej lęk. Zdarzały się również przypadki, że winą za śmierć noworodka obarczano akuszerkę, zaś oskarżenie o stosowanie magii ułatwiało wymierzanie kary takiej osobie. Jednak ważniejszym czynnikiem w przypadku posądzania o czary była nie wykonywana profesja, ale status społeczny. Osoby żyjące na granicy ubóstwa były najbardziej narażone na procesy o czarostwo. Żebraczki czy jałmużnicy utrzymujący się z datków były osobami, którymi zaczęto gardzić oraz uważać za "niewygodne” w czasach, kiedy epidemie i wojny dziesiątkowały ludność. Także „zdziwaczałość” osób starszych tworzyła z nich łatwy cel. Niepokój budziły również samotne kobiety - właścicielki małych nieruchomości ${ }^{20}$.

Do wzrostu liczby procesów o czary przyczyniała się także sytuacja polityczno-religijno-gospodarcza w poszczególnych państwach. Na przełomie XV i XVI w., kiedy przez obszary europejskie przetaczały się wojny oraz choroby, a bieda była zjawiskiem powszechnie występującym, niekorzystne zmiany przypisywano działaniom Szatana, zaś unicestwienie czarownicy miało przywrócić ład i porządek ${ }^{21}$. Oskarżenie o czary mogło mieć swój podtekst polityczny, w momencie gdy oskarżonymi były osoby z wyższych klas społecznych pragnące odnosić sukcesy w świecie polityki. Oskarżenie konkurenta (bądź członków jego rodziny) o stosowanie praktyk magicznych było skutecznym sposobem walki politycznej i w zasadzie przekreślało jego karierę. W Polsce nie bez znaczenia dla sądu był fakt kto wnosił oskarżenie oraz kim był sam oskarżony. W przypadku kiedy osoba o wysokim statusie społecznym była oskarżana przez osobę nisko urodzoną, która nie posiadała wpływów politycznych, sąd nie przywiązywał wagi do przedstawianych oskarżeń ${ }^{22}$. Sytuacjami nieracjonalnymi wydają się być także te, w których dziecko chciało zemścić się na swoim rodzicu (najczęściej matce), zmuszającym je do poślubienia nieodpowiedniej w oczach dziecka kandydatki. Nie powinien więc dziwić fakt, iż do grona kobiet najczęściej posądzanych o czary należały mężatki. W Szkocji między wiekiem XVI a XVIII liczba mężatek posądzonych o czary wynosiła 245 , podczas gdy wdów było jedynie 67 , a panien 7. Sytuacja przedstawiała się podobnie w innych państwach, hrabstwach i miastach, jak na przykład Wenecji, Bazylei, Genewie, Salemie, czy

20 Kobietom niezależnym finansowo przypisywano związek z Szatanem, który w zamian za posłuszeństwo obiecywał im korzyści materialne; ibidem, s. 207-209.

21 Pozbycie się czarownicy pomagało w utrzymaniu równowagi psychicznej ludzi, którzy winą za wszelkie niepowodzenia obarczali czarownice; ibidem, s. 215-218.

22 B. Baranowski, Procesy czarownic w Polsce..., s. 84-85. 
Kencie. Powodem oskarżania o czary wdów czy panien był brak zależności od męża, który władałby ich majątkiem. Dodatkowo w przypadku wdów dochodziła również kwestia braku kontroli ojca, a w XVI w., kiedy zamykano klasztory, do których wdowy mogłyby się udać, stawały się one niezależne, co było uważane za nienaturalny stan rzeczy ${ }^{23}$.

$\mathrm{Z}$ zarzutami dotyczącymi uprawiania magii musiały również liczyć się kobiety posiadające ambicje polityczne, choć te przecież zajmowały z reguły wyższy status społeczny. Do przykładów takich kobiet należy zaliczyć Elżbietę Woodville, żonę Edwarda IV Yorka, króla Anglii, posiadającą ogromny wpływ na męża, który uczynił z niej wykonawczynię swojego testamentu w razie swej przedwczesnej śmierci, a także jedną z trzech osób posiadających klucze do królewskiego skarbca. Nadano jej także prawo do aranżowania małżeństw ich córek (posiadali wspólnie przynajmniej dziesięcioro dzieci). Powyższe przywileje przyczyniły się do tego, iż Elżbieta Woodville była niejednokrotnie posądzana o czary zarówno za życia Edwarda IV, jak również po jego śmierci ${ }^{24}$. Inną postacią, która (w odróżnieniu od Elżbiety Woodville) swoje ambicje przypłaciła życiem była Anna Boleyn, druga żona Henryka VIII. Znienawidzona przez większość poddanych, została oskarżona o czary, za pomocą których miała uwieść Henryka, a który to pod ich wpływem odwrócił się od swojej bogobojnej żony Katarzyny Aragońskiej. Anna Boleyn zapewne nie straciłaby życia, gdyby zamiast chęci ingerowania w politykę państwa dała królowi upragnionego męskiego potomka. Tymczasem wydała na świat jedynie księżniczkę (przyszłą królową Elżbietę I) ${ }^{25}$. W zdecydowanie większej ilości przypadków to kobiety, a nie mężczyźni były posądzane o czary. W Świętym Cesarstwie Rzymskim (w granicach z 1648 r.) kobiety stanowiły $76 \%$ wszystkich osób posądzonych o czary.

23 B. P. Levack, Polowanie na czarownice..., s. 204-207.

24 Ponieważ Elżbieta miała się rzekomo wywodzić z rodu boginki wodnej Meluzyny, nazywano ją czarownicą, która omamiła króla i chciała umożliwić objęcie stanowisk w państwie całej swojej rodzinie. Zarówno ona, jak i jej matka Jakobina, do końca życia zmagały się z zarzutami o czary; P. Gregory, D. Baldwin, M. Jones, Kobiety Wojny Dwu Róż. Księżna, królowa i królowa matka, tłum. U. Gardner, Poznań 2011, s. 135-209.

25 Anna Boleyn została oskarżona o czary krótko po tym, jak urodziła martwego chłopca, który - według badań - miał zniekształcone ciało, co miało stanowić dowód na to, że jego matka była czarownicą. Także anatomia Anny nie pomogła podczas jej procesu - miała kikut szóstego palca, który kojarzono z czarostwem. Anna uniknęła losu czarownicy i ostatecznie, dzięki łaskawości Henryka VIII, została ścięta; E. Ives, Życie i śmierć Anny Boleyn, tłum. E. Stępkowska, Kraków 2012, s. 331-418. 
W tym samym przedziale czasowym na Węgrzech posądzono o czary o 1300 kobiet więcej niż mężczyzn. Sytuacja, w której kobiety były głównymi podejrzanymi o czary występowała w większości państw europejskich. Powodem takiego stanu rzeczy było przypisywanie kobietom słabszej moralności, podatności na wpływy Szatana, a także fakt, iż w swojej pracy, na przykład jako akuszerki czy zielarki, miały do czynienia z roślinami, które kojarzono nieodłącznie z magią. Jednakże, w krajach takich jak Normandia, Estonia, Islandia czy Rosja to mężczyźni byli częściej oskarżani o czarostwo. Szamani i uzdrowiciele, ale także chcący odnieść sukces polityczny mężczyźni, a nawet pasterze, mogli zostać oskarżeni o kontakty z Szatanem ${ }^{26}$.

\section{Czarostwo - prawdy i mity}

Oskarżanie o czary i konszachty z Szatanem niejednokrotnie było związane $\mathrm{z}$ sytuacją polityczną w państwie. Miało ono za zadanie pozbycie się przeciwnika. Zdarzały się sytuacje, w których monarchowie oskarżali papiestwo o kontakty z diabłem, w celu wymuszenia na nim spełnienia swoich postulatów ${ }^{27}$. Mimo iż Inkwizycja odrzucała tortury jako środek prowadzący do przyznania się do winy, to jednak w różnych krajach stosowano je ze zdwojoną siłą, co w konsekwencji wymuszało barwne zeznania osób, rzekomo winnych czarostwa. Ofiarami najczęściej były kobiety, niejednokrotnie znajdujące się w trudniejszej sytuacji finansowej od mężczyzn, a które uznawano za czarownice, ponieważ trudniąc się znachorstwem nie mogły zaprzeczyć stosowaniu ziół w celu leczenia czy uśmierzania bólu ${ }^{28}$. Niemniej jednak, mity związane z postaciami czarownic, jak chociażby latanie w powietrzu, organizowanie sabatów czy korzystanie ze słynnych kociołków czarownic są jedynie przeinaczeniem, nadinterpretacją oraz uogólnieniem sytuacji, jaka miała miejsce między XV a XVIII w. ${ }^{29}$ Jednakże najważniejszym spostrzeżeniem

26 Oskarżenie o bycie czarownikiem groziło także mężczyznom z wyższych sfer, kiedy rzekome czarownice podawały ich nazwiska w czasie przesłuchań podczas tortur. Niektórzy z nich byli sądzeni w powiązaniu z procesami o herezję; B. P. Levack, Polowanie na czarownice..., s. 187-198.

27 Mowa tutaj o francuskim królu Filipie IV Pięknym, który oskarżał papieża Bonifacego VIII o kontakty z demonami. Mimo że pomówienia te były mało wiarygodne, przeciwnicy papieża rozpowszechniali je jeszcze po jego śmierci; D. Alexander, Spellbound. From Ancient Gods..., s. 157.

B. Baranowski, Pożegnanie z diabłem i czarownica, Łódź 1965, s. 5-10.

Doniesienia o lataniu na miotle czy o sabacie czarownic mogły się wiązać z zażywaniem substancji halucynogennych, mogących wywołać uczucie unoszenia się 
powinno być zrozumienie, iż prześladowanie czarownic miało miejsce nie w średniowieczu, jak uważa wielu ludzi, ale w czasach wczesnonowożytnych. Za autora teorii, mówiącej o tym, że polowanie na czarownice miało miejsce wcześniej, uważa się francuskiego pisarza Lamothe-Langon'a, który opierając się na niedokładnych doniesieniach kronikarza Williama Bardina, zawyżał dodatkowo liczbę osób posądzonych o czary, a Inkwizycję, która walczyła $\mathrm{z}$ heretykami, stawiał w roli głównego ciemiężyciela skazywanej ludności ${ }^{30}$. W rzeczywistości, w XIII w., kiedy instytucja Inkwizycji została ustanowiona, mamy do czynienia z pojedynczymi oskarżeniami, które osiągnęły swoje apogeum dopiero trzy wieki później, a których inicjatorami byli głównie zwykli ludzie chcący unieszkodliwić swojego wroga, bądź też zostali do tego zmuszeni drogą tortur i prześladowań.

\section{Bibliografia}

ALEXANDER D., Spellbound. From Ancient Gods to Modern Merlins. A Time Tour of Myth and Magic, London 2002 (wyd. polskie: Czarownice, wróżbici, szamani. Podróż przezświat mitów i magii, tłum. J. Korpanty, Warszawa 2008).

BARANOWSKI B., Procesy czarownic w Polsce w XVII i XVIII wieku, Łódź 1952. BASCHWITZ K., Czarownice. Dzieje procesów o czary, Warszawa 1999.

BIOQUE B., Wstęp do magii, Warszawa 2014.

GREGORY P., BALDWIN D., JONES M., The Women of the Cousins' War: The Duchess, The Queen and The King's Mother, New York-London-Toronto 2011. IVES E., The Life and Death of Anne Boleyn, Oxford 2005.

LEVACK B. P., Polowanie na czarownice w Europie wczesnonowożytnej, Wrocław 2009.

Mitologie Świata. Celtowie, red. J. Kałużna-Ross, Warszawa 2007.

PARANDOWSKI J., Mitologia. Wierzenia i podania Greków i Rzymian, Londyn 1992.

Pismo Święte. Stary i Nowy Testament, red. ks. M. Peter, ks. M. Wolniewicz, Poznań 2003.

Słownik PWN, http://sjp.pwn.pl/.

w powietrzu. Kocioł czarownicy (występujący w bajkach) utożsamiano z najgorszym z możliwych przestępstw zabicia i jedzenia dzieci; D. Alexander, Spellbound. From Ancient Gods..., s. 210-222.

30 Ibidem, s. 90-91. 